www.mdpi.com/journal/pharmaceutics

Article

\title{
Compaction Behavior of Isomalt after Roll Compaction
}

\section{Julian Quodbach *, Johanna Mosig and Peter Kleinebudde}

Institute of Pharmaceutics and Biopharmaceutics, Heinrich-Heine-University, Universitaetsstrasse 1, 40225 Duesseldorf, Germany

* Author to whom correspondence should be addressed; E-Mail: Julian.Quodbach@hhu.de; Tel.: +49-211-81-14513; Fax: +49-211-81-14251.

Received: 5 July 2012; in revised form: 16 August 2012 / Accepted: 18 September 2012 /

Published: 27 September 2012

\begin{abstract}
The suitability of the new isomalt grade galenIQ ${ }^{\mathrm{TM}} 801$ for dry granulation and following tableting is evaluated in this study. Isomalt alone, as well as a blend of equal parts with dibasic calcium phosphate, is roll compacted and tableted. Particle size distribution and flowability of the granules and friability and disintegration time of the tablets are determined. Tensile strength of tablets is related to the specific compaction force during roll compaction and the tableting force. In all cases, the tensile strength increases with raising tableting forces. The specific compaction force has a different influence. For isomalt alone the tensile strength is highest for tablets made from granules prepared at $2 \mathrm{kN} / \mathrm{cm}$ and $6 \mathrm{kN} / \mathrm{cm}$ and decreases at higher values, i.e., $>10 \mathrm{kN} / \mathrm{cm}$. Tensile strength of the blend tablets is almost one third lower compared to the strongest tablets of pure isomalt. Friability of pure isomalt tablets is above the limit. Disintegration time is longest when the tensile strength is at its maximum and decreases with higher porosity and lower tensile strengths. Isomalt proves to be suitable for tableting after roll compaction. Even though the capacity as a binder might not be as high as of other excipients, it is a further alternative for the formulation scientist.
\end{abstract}

Keywords: isomalt; roll compaction; work hardening; recompression; compactibility

\section{Introduction}

Isomalt is a polyol derived from sucrose. Advantages of this excipient are its sweet taste, which is supposed to allow taste masking, the low glycemic and insulinemic response [1], and the ability to be 
compacted directly. With regard to infantile patients, also the lack of cariogenicity is important [2]. The marketed products differ mainly in the particle size distribution and the chemical composition. Isomalt consists of varying amounts of 1-O-D-glucopyranosyl-D-mannitol dihydrate (GPM) and 6-O-D-glucopyranosyl-D-sorbitol (GPS). Since the water solubility of GPS is higher, the marketed products show deviating physicochemical behavior [3]. Ndindayino et al. [4,5] investigated the performance of isomalt in direct compression. It was discovered, that isomalt exhibits plastic deformation and elastic recovery mostly in the die. One study determined that isomalt is also an option as diluent for orally disintegrating tablets [6]. Moreover, isomalt was found to be beneficial as excipient for wet granulation with acetaminophen [7].

Roll compaction/dry granulation is a frequently used operation in the pharmaceutical industry. As described in literature excipients can lose their ability to form strong tablets after roll compaction/dry granulation [8-10]. Due to this phenomenon called work hardening, it is favourable to know how materials behave on recompression. galenIQ ${ }^{\mathrm{TM}} 801$ is a new brand of isomalt consisting of about $75 \%$ GPS and 25\% GPM. It is supposed to be an easy to granulate, agglomerate and compact filler/binder. This study investigates the preservation of its compactibility after roll compaction.

\section{Materials and Methods}

\subsection{Materials}

Isomalt (galenIQ ${ }^{\mathrm{TM}}$ 801, Beneo Palatinit GmbH, Germany), dibasic calcium phosphate anhydrite (DCP, Dicafos C 92-05, Chemische Fabrik Budenheim KG, Budenheim, Germany), fumed silica (Aerosil $^{\circledR}$ 200, Evonik Degussa GmbH, Germany) and magnesium stearate (Bärlocher, Germany) were used. Isomalt and DCP were sieved through a $2000 \mu \mathrm{m}$ sieve. For the mixture equal parts $(w / w)$ of isomalt and dibasic calcium phosphate were blended for 10 min in a Turbula mixer (T2C, Willy A. Bachofen AG, Basel, Switzerland).

\subsection{Methods}

\subsubsection{Roll Compaction}

Two different powders were granulated. The first one was pure isomalt, the second one a blend of equal parts of isomalt and DCP. They were granulated with a Minipactor 250/25 (Gerteis Maschinen + Prozessengineering AG, Jona, Switzerland) equipped with a star granulator and a $1 \mathrm{~mm}$ sieve. The star granulator was set to move $120^{\circ}$ clockwise and $180^{\circ}$ counterclockwise with a gap width of $1 \mathrm{~mm}$ and a rotor speed of $40 \mathrm{rpm}$ clockwise and $60 \mathrm{rpm}$ counterclockwise. Speed of the rolls was set to $1 \mathrm{rpm}$ with a gap width of $2.0 \mathrm{~mm}$. Specific compaction forces were $2 \mathrm{kN} / \mathrm{cm}, 6 \mathrm{kN} / \mathrm{cm}, 10 \mathrm{kN} / \mathrm{cm}$ and $14 \mathrm{kN} / \mathrm{cm}$ for isomalt. The isomalt batch produced at $2 \mathrm{kN} / \mathrm{cm}$ showed no promising results, thus no DCP blend was roll compacted at this specific compaction force.

\subsubsection{Analysis of Powders and Granules}

The true density was acquired with a helium pycnometer (AccuPyc 1330, Micromeritics GmbH, Aachen, Germany; $n=3$ ). Laser diffraction (Helos, Sympatec GmbH, Clausthal-Zellerfeld, Germany) 
was used to evaluate the particle size distribution of raw materials, whereas sieve analysis was performed to characterize the granules using a sieve shaker (Vibro, Retsch GmbH, Haan, Germany) for $5 \mathrm{~min}$ with an amplitude of $1 \mathrm{~mm}$ with $1400 \mu \mathrm{m}, 1000 \mu \mathrm{m}, 710 \mu \mathrm{m}, 500 \mu \mathrm{m}, 355 \mu \mathrm{m}, 250 \mu \mathrm{m}$, $180 \mu \mathrm{m}$, and $100 \mu \mathrm{m}$ sieves. The residue was further sieved with an air-jet sieve (AS 200 jet, Retsch $\mathrm{GmbH})$ for $2 \mathrm{~min}$ with an under-pressure of $1700 \mathrm{~Pa}$ using $90 \mu \mathrm{m}, 63 \mu \mathrm{m}$ and $32 \mu \mathrm{m}$ sieves $(n=2)$. The results were interpolated using the software OriginPro 8.5G (OriginLab Corporation, Northampton, MA, USA) to acquire the $x_{10}, x_{50}$ and $x_{90}$ values.

The Hausner factor was calculated from tapped and bulk density, measured with a volumetric analyzer (J. Engelsmann AG, Ludwigshafen, Germany; $n=3$ ). Also, measurements with a ring shear cell (RST-01.pc, Dr.-Ing. Dietmar Schulze, Wolfenbüttel, Germany) provided the flow function coefficient $\left(\mathrm{ff}_{\mathrm{c}}\right)$ values of granules and powders $(n=3)$ to describe the flow properties.

\subsubsection{Tableting and Characterization of Tablets}

Prior to tableting, $0.5 \%$ magnesium stearate were added to the granules and powders and mixed for $2 \mathrm{~min}$ in the Turbula mixer. Ungranulated powders were mixed beforehand with additional $0.5 \%$ of Aerosil. All batches were tableted on a rotary die press (Pressima, IMA Kilian, Köln, Germany) set to $15 \mathrm{rpm}$ and compaction forces of $3 \mathrm{kN}, 6 \mathrm{kN}, 9 \mathrm{kN}, 12 \mathrm{kN}$ and $15 \mathrm{kN}$. Flat faced tablets of a weight of $350 \mathrm{mg}$ and a diameter of $12 \mathrm{~mm}$ were produced. Tablet height, weight, diameter and breaking force were determined with a MultiCheck 5.1, friability with a TA friability tester (both Erweka GmbH, Heusenstamm, Germany) according to $\mathrm{Ph}$. Eur. 7.0. Breaking force and tablet size were used to calculate the tensile strength according to Fell and Newton [11]. A DT2 (Sotax, Allschwill/Basel, Switzerland) was used to measure the disintegration time (Ph. Eur. 7.0) in water.

\subsubsection{Nomenclature}

Batch nomenclature is devised according to the following scheme:

Granules $(G)$ or tablets $(T)$-isomalt $(A)$ or isomalt-DCP (B)-specific compaction force $(\mathrm{kN} / \mathrm{cm})$ tableting force $(\mathrm{kN})$ (if tableted)

e.g., T-A-2_15 refers to isomalt tablets roll compacted with $2 \mathrm{kN} / \mathrm{cm}$ and tableted with $15 \mathrm{kN}$.

\section{Results and discussion}

\subsection{Characterization of Granules}

The flowability is characterized in terms of the $\mathrm{ff}_{\mathrm{c}}$ value and the Hausner factor. $\mathrm{ff}_{\mathrm{c}}$ values below 4 describe cohesive behavior, the range from 4 to 10 points to easy-flowing materials, whereas an $\mathrm{ff}_{\mathrm{c}}$ value greater 10 means free-flowability [12]. The results are given in Table 1. Even the lowest specific compaction force of $2 \mathrm{kN} / \mathrm{cm}$ improves the flowability of pure isomalt from cohesive $\left(\mathrm{ff}_{\mathrm{c}}=3.24 \pm 0.02\right)$ to easy flowing $\left(\mathrm{ff}_{\mathrm{c}}=6.80 \pm 0.71\right)$. Specific compaction forces of $6 \mathrm{kN} / \mathrm{cm}$ and higher produce granules which are all free flowing with $\mathrm{ff}_{\mathrm{c}}$ values above 10. The Hausner factor behaves accordingly, decreasing from 1.33 for the uncompacted isomalt to 1.11 for granules produced with a specific compaction force of $14 \mathrm{kN} / \mathrm{cm}$. 
Table 1. Flow parameters and particle size percentiles (mean, coefficient of variation $<15 \%$, only $x_{10}$ of G-A-6, $x_{10}$ and $x_{50}$ of G-B-6 and $x_{10}$ of G-B-14 exceed $15 \%$ ).

\begin{tabular}{|c|c|c|c|c|c|c|c|c|c|}
\hline \multirow{2}{*}{$\begin{array}{c}\text { Specific compaction } \\
\text { force }[\mathrm{kN} / \mathrm{cm}]\end{array}$} & \multicolumn{5}{|c|}{ Isomalt granules } & \multicolumn{4}{|c|}{ Isomalt-DCP granules } \\
\hline & $\mathbf{0}$ & 2 & 6 & 10 & 14 & $\mathbf{0}$ & 6 & 10 & 14 \\
\hline Hausner factor & 1.33 & 1.21 & 1.16 & 1.15 & 1.11 & 1.44 & 1.24 & 1.15 & 1.15 \\
\hline $\mathrm{ff}_{\mathrm{c}}$ value & 3.6 & 6.8 & 12.1 & 16.6 & 16.5 & 3.2 & 4.8 & 10.1 & 8.4 \\
\hline$x_{10}[\mu \mathrm{m}]$ & 1.7 & 25.0 & 141.5 & 184.0 & 186.5 & 1.0 & 36.6 & 37.5 & 41.0 \\
\hline$x_{50}[\mu \mathrm{m}]$ & 17.7 & 546 & 642 & 607 & 617 & 7.2 & 556 & 590 & 554 \\
\hline$x_{90}[\mu \mathrm{m}]$ & 44.6 & 923 & 934 & 921 & 938 & 31.1 & 920 & 927 & 928 \\
\hline
\end{tabular}

Similar results are obtained for the isomalt-DCP batches. The $\mathrm{ff}_{\mathrm{c}}$ value increases with higher specific compaction forces up to $10 \mathrm{kN} / \mathrm{cm}$, yet displays a slight drop below the free flowing mark of 10 with an $\mathrm{ff}_{\mathrm{c}}$ value of $8.41 \pm 0.06$ at $14 \mathrm{kN} / \mathrm{cm}$. This can be due to brittle behavior of the excipient after being compacted with the highest specific compaction force, thus creating more fines. In this case, the $\mathrm{ff}_{\mathrm{c}}$ value is a more discriminating and accurate indicator for the flowability than the Hausner factor, which is 1.15 for both, the $10 \mathrm{kN} / \mathrm{cm}$ and $14 \mathrm{kN} / \mathrm{cm}$ batch.

The increased flowability can be explained by the strong increase in particle size due to roll compaction (Table 1). Laser diffraction reveals an $x_{90}$ of $44.64 \pm 1.16 \mu \mathrm{m}$ for pure isomalt and $31.05 \pm 1.02 \mu \mathrm{m}$ for the isomalt-DCP blend. After roll compaction the $x_{90}$ of pure isomalt as well as isomalt-DCP granules is in all cases above $900 \mu \mathrm{m}$. Yet, the isomalt-DCP granules have only small $x_{10}$ values of around $37 \mu \mathrm{m}$ which explain the lower $\mathrm{ff}_{\mathrm{c}}$ values compared to pure isomalt granules. Only the $2 \mathrm{kN} / \mathrm{cm}$ batch of isomalt granules has an equally small $\mathrm{x}_{10}$ value, specific compaction forces $\geq 6 \mathrm{kN} / \mathrm{cm}$ lead to an $x_{10}$ of $\geq 140 \mu \mathrm{m}$. The $x_{50}$ value increases from $546 \mu \mathrm{m}$ to $642 \mu \mathrm{m}$ in the same step. The largest $x_{50}$ value is at $6 \mathrm{kN} / \mathrm{cm}$ for isomalt granules $(642 \mu \mathrm{m})$ and at $10 \mathrm{kN} / \mathrm{cm}$ for isomalt-DCP granules $(590 \mu \mathrm{m})$. It decreases again at higher specific compaction forces, indicating a maximum of plastic deformation at these forces. The material begins to behave brittle as soon as the specific compaction force is raised and the particle size decreases.

\subsection{Characterization of Tablets}

As a measure of compactibility, the tensile strength was plotted against the tableting force. As depicted in Figure 1a, it is evident that large specific compaction forces (i.e., $\geq 10 \mathrm{kN} / \mathrm{cm}$ ) result in weaker tablets of pure isomalt. T-A-2_15 and T-A-6_15 have tensile strengths up to $1.5 \mathrm{MPa}$, however tablets of granules produced with a specific compaction force of $\geq 10 \mathrm{kN} / \mathrm{cm}$ have lower tensile strengths. Batch T-A-14_15 displays a drop to below $1 \mathrm{MPa}$. Only one batch of ungranulated isomalt could be produced (T-A-0_15) because lower tableting forces lead to soft and easily breaking tablets. The difference in tensile strength between ungranulated isomalt and isomalt granulated at low specific compaction forces is small, indicating only little work hardening.

The tablets produced with the isomalt-DCP blend behave differently (Figure 1b). The differences in tensile strength are small across all compaction forces. Yet, the overall tensile strength is in all cases lower than the one of pure isomalt tablets. The strongest tablets made from granules are compacted 
with a specific compaction force of $6 \mathrm{kN} / \mathrm{cm}$ and tableted with $15 \mathrm{kN}$ (T-B-6_15). But even in this case, the tensile strength is in average below $0.9 \mathrm{MPa}$.

Figure 1. (a) Compactibility of isomalt tablets; (b) Compactibility of isomalt-DCP tablets. (mean $\pm \mathrm{SD}, n=10)$.

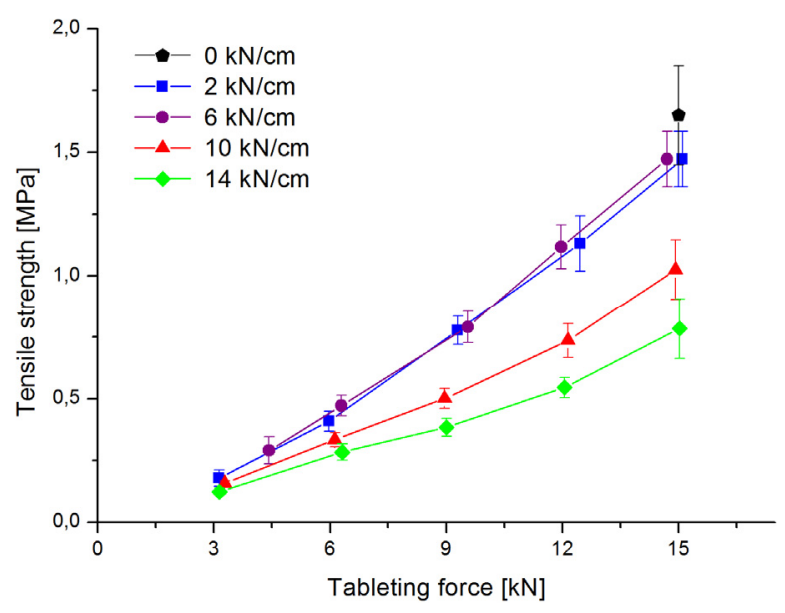

a

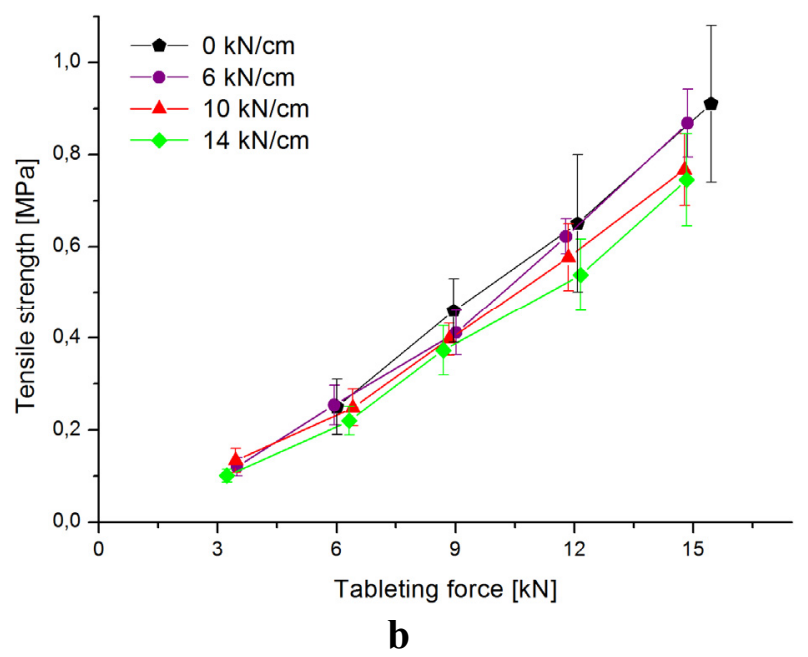

b

These results mirror in the friability test results. None of the isomalt-DCP tablet batches passes the test. It can be assumed that the brittle behavior of DCP is dominant, thus causing weaker tablets. Pure isomalt tablets roll compacted at $14 \mathrm{kN} / \mathrm{cm}$ were affected most from work hardening, as these tablets also fail the test (Table 2). The friability test is successful for tableting forces higher than $9 \mathrm{kN}$ and specific compaction forces of $2 \mathrm{kN} / \mathrm{cm}$ and $6 \mathrm{kN} / \mathrm{cm}$. Also, batch T-A-6_9 passes the test.

Table 2. Friability test results of isomalt tablets according to $\mathrm{Ph}$. Eur. 7.0.

\begin{tabular}{rcccc}
\hline & $\mathbf{2 . 0} \mathbf{~ k N} / \mathbf{c m}$ & $\mathbf{6 . 0} \mathbf{~ k N} / \mathbf{c m}$ & $\mathbf{1 0 . 0} \mathbf{~ k N} / \mathbf{c m}$ & $\mathbf{1 4 . 0} \mathbf{~ k N} / \mathbf{c m}$ \\
\hline $3 \mathrm{kN}$ & not passed & not passed & not passed & not passed \\
$6 \mathrm{kN}$ & not passed & not passed & not passed & not passed \\
$9 \mathrm{kN}$ & not passed & $0.91 \%$ & not passed & not passed \\
$12 \mathrm{kN}$ & $0.62 \%$ & $0.75 \%$ & not passed & not passed \\
$15 \mathrm{kN}$ & $0.74 \%$ & $0.60 \%$ & not passed & not passed \\
\hline
\end{tabular}

Ritschel defines the approximate target value of breaking force as $10 \mathrm{~N}$ times the diameter in millimeter [13]. The tablets compressed in this study have a diameter of $12 \mathrm{~mm}$ and a height of about $2.3 \mathrm{~mm}$ in average, implying a target breaking force of roughly $120 \mathrm{~N}$. Even the strongest produced tablets show a breaking force of only $40 \mathrm{~N}$.

Furthermore, the disintegration time according to $\mathrm{Ph}$.Eur. was measured. In most cases, the tablets disintegrate as expected. The higher the specific compaction and tableting force, the longer the tablets need to disintegrate (Figure 2a,b). Isomalt-DCP tablets tend to disintegrate slower than isomalt tablets in most cases. This can be due to the very low water solubility of DCP.

During the dry granulation and tableting processes, the intraparticular and interparticular porosities are affected. Whereas the intraparticular porosity is mainly altered during roll compaction, the interparticular porosity decreases with increasing tableting forces. This explains why some batches 
disintegrate slowly, even though the tableting force was kept low. For example, T-A-14_3 disintegrates within the same time range as T-A-2_9, albeit the tableting force is tripled. The intraparticular porosity is too small to allow quick wicking. The tensile strength of T-A-2 batches is similar to that of T-A- 6 batches, yet the tablets disintegrate faster at $6 \mathrm{kN}$ and $9 \mathrm{kN}$. It can be assumed, that the higher intraparticular porosity due to the lower specific compaction force facilitates the entry of water and therefore accelerates disintegration. The data suggest that the specific compaction force has a higher impact on the disintegration time than the tableting force. Yet, the differences in disintegration time decrease at compression forces $\geq 9 \mathrm{kN}$. The impact of the specific compaction force also decreases with increasing compressions forces. Only pure isomalt roll compacted with $14 \mathrm{kN} / \mathrm{cm}$ displays higher disintegration times compared to the other batches.

Figure 2. (a) Disintegration time of isomalt tablets. (b) Disintegration time of isomalt-DCP tablets. $(n=6$, mean $\pm \mathrm{SD})$.

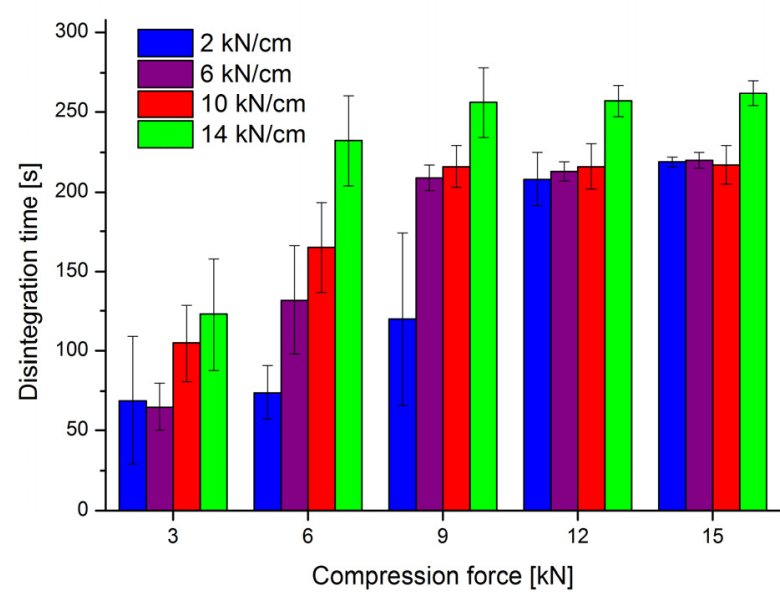

a

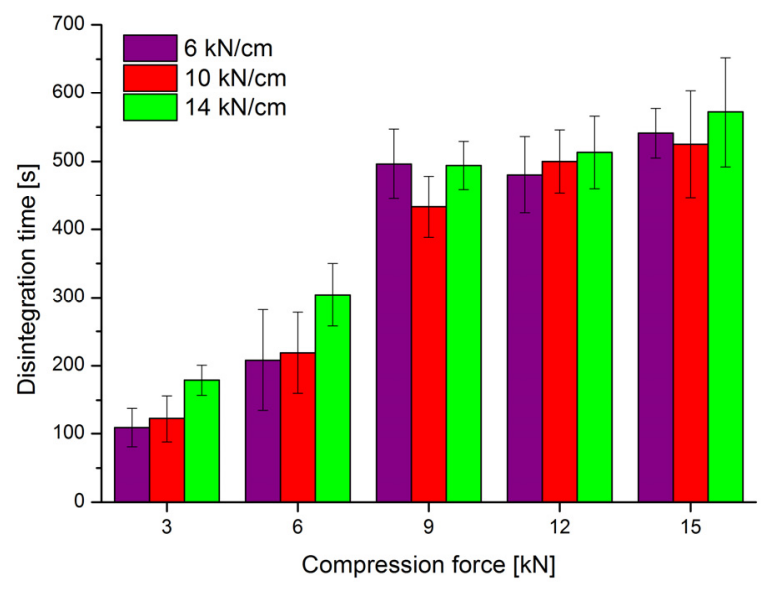

b

\section{Conclusion}

Work hardening also affects the new isomalt brand galenIQ ${ }^{\mathrm{TM}}$ 801. Increasing the specific compaction force during dry granulation resulted in decreasing tensile strengths of produced tablets. However, it is still shown that isomalt is suitable for dry granulation and further tableting. A specific compaction force of $6 \mathrm{kN} / \mathrm{cm}$ seems to be the best setting for roll compaction, resulting in freely flowing granules as well as tablets with the highest tensile strength.

It must be mentioned, however, that the compressed tablets were not comparable with marketed products in terms of size and composition. The thickness ranged between $1.90 \mathrm{~mm}$ and $3.05 \mathrm{~mm}$ for a $12 \mathrm{~mm}$ diameter, which is unusually flat and resulted in weak compacts not on a par with standard tablets. The tablet size was particularly low merely because a limited amount of substance was available. The friability test failed due to the fact that the tablets broke apart rather than because of abrasion. Whether tablets with a common drug load and thickness are sufficiently strong needs to be further investigated. 


\section{Acknowledgments}

The authors wish to thank Ali Rami and Patrick Scholz for conducting the experiments.

\section{Conflict of Interest}

The authors declare no conflict of interest.

\section{References}

1. Petzoldt, R. Palatinite in type II diabetics: Effect on blood-glucose, serum-insulin, C-peptide and free fatty acids. Deutsch. Med. Wochenschr. 1982, 107, 1910-1913.

2. Gehring, F. The sugar substitute Palatinit ${ }^{\circledR}$ with special regard to microbiological and caries-prophylactic aspects. Zeitschrift für Ernährungswissenschaft 1981, 20, 96-106.

3. Bolhuis, G.K. Excipients for direct compaction-An update. Pharm. Dev. Technol. 2006, 11, 111-124.

4. Ndindayino, F.; Henrist, D.; Kiekens, F.; Vervaet, C.; Remon, J.P. Characterization and evaluation of isomalt performance in direct compression. Int. J. Pharm. 1999, 189, 113-124.

5. Ndindayino, F.; Vervaet, C.; van den Mooter, G.; Remon, J.P. Direct compression and moulding properties of co-extruded isomalt/drug mixtures. Int. J. Pharm. 2002, 235, 159-168.

6. Chawla, M. Evaluation of galen IQ polymer in Tramadol Hydrochloride orally disintegrating tablet. Int. J. Drug Deliv. 2011, 3, 439-455.

7. Saska, Z. Effect of isomalt as novel binding agent on compressibility of poorly compactable paracetamol evaluated by factorial design. Powder Technol. 2010, 201, 123-129.

8. Kleinebudde, P. Roll compaction/dry granulation: Pharmaceutical applications. Eur. J. Pharm. Biopharm. 2004, 58, 317-326.

9. Kochhar, S.K.; Rubinstein, M.H.; Barnes, D. The effects of slugging and recompression on pharmaceutical excipients. Int. J. Pharm. 1995, 115, 35-43.

10. Malkowska, S.; Khan, K.A. Effect of re-conpression on the properties of tablets prepared by dry granulation. Drug Dev. Ind. Pharm. 1983, 9, 331-347.

11. Fell, J.T.; Newton, J.M. Determination of tablet strength by diametral-compression test. J. Pharm. Sci. 1970, 59, 688.

12. Schulze, D. Flow properties of powders and bulk solids (fundamentals). Available online: http://www.dietmar-schulze.de/grdle1.pdf (accessed on 24 September 2012).

13. Ritschel, W.A.; Bauer-Brandl, A. Die Tablette: Handbuch der Entwicklung, Herstellung und Qualitätssicherung (In German); Editio Cantor Verlag: Aulendorf, Germany, 2002; p. 518.

(C) 2012 by the authors; licensee MDPI, Basel, Switzerland. This article is an open access article distributed under the terms and conditions of the Creative Commons Attribution license (http://creativecommons.org/licenses/by/3.0/). 